\title{
PHILO OF ALEXANDRIA AND THE ORIGINS OF ONTO-THEOLOGY
}

\author{
Seweryn Blandzi
}

DOI: 10.17846/CL.2017.10.2.3-14

\begin{abstract}
BLANDZI, Seweryn. Philo of Alexandria and the Origins of Onto-theology. The author seeks an explanation for the genesis of onto-theology ascribed to Aristotle's "first philosophy", and points to Philo of Alexandria, who explicitly refers Aristotle's formula to on he on (Being as Being) directly to the God of the Bible. Moreover, the discovery is that the use of such a formula demonstrates Philo's inspiration by the Book Kappa of the Metaphysics. The author argues that this book was not written by Aristotle (see studies by Natorp, and Aubenque). Thus, the concept of Being used with reference to God cannot be ascribed to Aristotle but rather to the compiler of the Book K. Therefore, the originator of onto-theology is Philo not Aristotle, and it is Aristotle who under the "Being as Being" formula recommends considering Being in the sense of any object that can be studied and defined scientifically (see the Book Gamma of the Metaphysics).
\end{abstract}

Keywords: Being, God, Onto-theology, Metaphysics, First Philosophy, Aristotle, Philo of Alexandria, Natorp, Heidegger

\begin{abstract}
Abstrakt: BLANDZI, Seweryn. Filón Alexandrijský a pôvod onto-teológie. Autor sa snaží nájst’ vysvetlenie pre vznik onto-teológie, ktorá je pripisovaná Aristotelovej „prvej filozofii“, pričom poukazuje na Filóna Alexandrijského, ktorý Aristotelovu formuláciu to on hē on explicitne prepája priamo s Bohom Biblie. Tento objav dalej zahŕňa skutočnost', že používanie takejto formulácie demonštruje Filónovu inšpiráciu Knihou Kappa z diela Metafyzika. Autor tvrdí, že táto kniha nebola napísaná Aristotelom (vid’ štúdie od Natorpa a Aubenqueho). Koncept Bytia v spojitosti s Bohom preto nemôže byt pripísaný Aristotelovi, ale skôr zostavovatelovi Knihy K. Pôvodcom onto-teológie preto nie je Aristoteles ale Filón, pričom Aristoteles pod formuláciou „Bytie ako Bytie“ odporúča uvažovat’ o Bytí v zmysle akéhokolvek predmetu, ktorý môže byt’ vedecky skúmaný a definovaný (vid’ Knihu Gamma z diela Metafyzika).
\end{abstract}

Klúčové slová: Bytie, Boh, onto-teológia, Metafyzika, prvá filozofia, Aristoteles, Filón Alexandrijský, Natorp, Heidegger

When Martin Heidegger published in 1957 his essay entitled Die onto-theo-logische Verfassung der Metaphysik the conviction has been established that metaphysics, beginning with Aristotle, is basically an "onto-theology", i.e. a knowledge that culminates in the distinctive and specified form of Being (summum ens), i.e. the Divine Being. More specifically, metaphysics, according to Heidegger, is ambiguous in its very structure: "When metaphysics thinks of beings with respect to the ground that is common to all beings as such, then it is logic as onto-logic. When metaphysics thinks of beings as such as a whole, that is, with respect to the highest being which accounts for every thing, then it is logic as theo-logic" (Heidegger 1969, 70-71). In the Introduction that in 1949 was added to his lecture What Is Metaphysics held in 1929, Heidegger cites the books Gamma, Epsilon and Kappa of Aristotle's Metaphysics. He notes: "Metaphysics moves in the realm 
of $\partial \mathrm{o} v$ ก๊ $\mathrm{o} v$ [be-ing as be-ing]. Its formulating concerns be-ing as be-ing. In this way, metaphysics always formulates be-ing as such as a whole as the be-ingness [Seiendheit] of be-ing (the ovioi $\alpha$ [presence] of ov). But metaphysics formulates the be-ingness of be-ing in a twofold way: in the first place, as the entirety [das Ganze] of be-ing as such, in the sense of the most general (ôv katónov, Kouvóv [be-ing on the whole, what is in common]; and at the same time, however, as the entirety

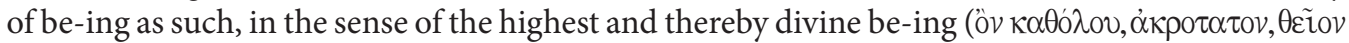
[the universal, what is the furthermost, divinity]). The emergence of be-ing was developed in its twofold sense especially in the metaphysics of Aristotle (cf. Metaphysics $\Gamma, \mathrm{E}, \mathrm{K}$ ).

Because it makes be-ing as be-ing an idea, metaphysics in itself is in fact two-in-one: the truth of be-ing in the most general sense and in the highest sense. In its essence it is ontology, in the narrower [scholastic] sense, and theology. This onto-theological essence of authentic philosophy

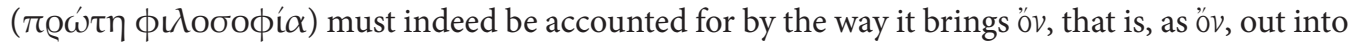
the open" (Heidegger 2015, 26).

What is of paramount importance for Heidegger, however, is not this ambiguity of metaphysics as such, but rather the fact that it is dominated by the theological component that utterly clouds the possibility of thinking the Being (Sein) itself. Being (Seiendes) is linked with God as the Highest Being that "grounds it as the first cause (ratio)". Being (Seiendes) participates in the Highest Being as the first (summum ens), and this relation is explained in metaphysics by reference to the conception of analogy or participation.

Paul Natorp was the first to have discovered this ambivalence in Aristotle. Yet at the same time, the scholar sought to free the Stagirite from it. He did that by pointing to the inauthenticity of the Book Kappa and by introducing an important correction to chapter Epsilon 1 that is shown to be of paramount importance for our understanding of "the first philosophy". The scholar does not regard the chapter as inauthentic, but rather damaged by interpolations and, therefore, misinterpreted. Indeed, one should not subsume under the notion of "the first philosophy" the two components: the ontological and the theological as well as the science of the Being as such (die allgemeine, für alle grundlegende [...] Wissenschaft) and the particular and supreme Being (vom stofflosen, unwandelbarer Sein, als der vornehmsten Gattung des Seienden, Natorp 1888a, 49). As Natorp notices, this would have clearly been a contradiction that could not be maintained (unleidlicher Widerspruch). In order for the contradiction to be resolved, it would suffice - according to him - to assume the concept of primacy in various senses: 1) in the sense of universal scope and 2) the highest dignity (value). When the two are combined, a contradiction arises. Heidegger's charge of the structure of metaphysics as being "two-headed", i.e., onto-theologic can, thereby, be recognized as valid with respect to the medieval metaphysics and not with respect to Aristotle's "first philosophy"(Natorp 1888a, 49).

In the present paper, I shall bring forth the crucial role of the emergence of the issue of ontotheology in the specific application of Aristotle's formula of $\tau$ o ô $v$ ño God of the Old Testament by Philo of Alexandria. This seems to have been unnoticed so far.

\section{Towards the Theologization of Being}

The teachings of the Old Testament, regarded as revelation, have become the first and most important of the non-Greek sources that have affected the reborn Platonism of the 1st and 2nd century (Plutarch, Numenius). The teachings have been delivered to the Greek thinkers via the interpretation put forward by Philo of Alexandria. Born at the end of the old era and influenced by the Judaic as well as the Hellenic culture, the thinker left a rich production that shows the dominance of the religious aspect and at the same time remains imbued with Greek 
philosophy. Philo found the Greek language even in the Holy Books, as he used the 3rd century B.C. translation of the Bible, known as the Septuagint.

When reading the Bible, Philo interpreted it allegorically chiefly in the light of Plato's philosophy ${ }^{1}$. It was this philosophy that greatly shaped his exegetical views on the nature of God and the spiritual world in particular. Philo was also familiar with the exoteric and the acroamatic production of Aristotle, from who he draws what - at least in his opinion - is consistent with Platonism. Apart from Plato's philosophy combined with Pythagoreanism, certain influence has been exerted on Philo by the Stoic philosophy. This, however, he sought to differentiate from Platonism in a similar manner that he tried to refine Plato's philosophy from all skeptic contaminations so as to interpret some of its elements in accord with the monotheistic theology.

Plato's absolutizing of ideas as Demiurge-independent algorithms was not particularly appealing to Philo. He accepted though the understanding of ideas as paradigms attributed to God as his thoughts, placing, thereby, God above the ideas. The ideas function here as incorporeal archetypes,

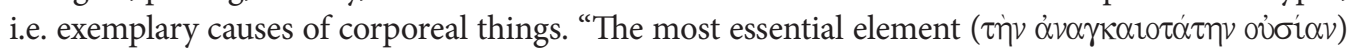
of their being, namely the archetypal patterns of all qualities in what exists, and on which the form and dimensions of each separate thing was modeled" (Philon. De specialibus legibus I, 327,5 -

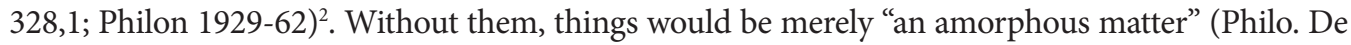
specialibus legibus I, 328,4; Philo 1929-62)3. "For when out of that confused matter God produced all things, He did not do so with His own handiwork, since His nature, happy and blessed as it was, forbade that He should touch the limitless chaotic matter. Instead He made full use of the incorporeal potencies well denoted by their name of Forms to enable each kind to take its appropriate shape" (Philo. De specialibus legibus I, 329, 1-5; Philo 1929-62) ${ }^{4}$.

Thus, incorporeal God proves to be transcendent to the world. "For not even the whole world would be a place fit for God to make His abode, since God is His own place, and He is filled by Himself, and sufficient for Himself, filling and containing all other things in their destitution and barrenness and emptiness, but Himself contained by nothing else, seeing that He is Himself One and the Whole" (Philo. Legum allegoriae, I, 44, 1 - 45, 1; Philo 1929-62)

The divine transcendence contains also the intelligible world that was created by him. Thus, in Philo's view the ideas are not immortal and unbegotten, as they are in Plato, but rather created by God's thought.

An important hint concerning the nature of the Highest Being is to be found in the second book of the Legum allegoriae (Philo. Legum allegoriae, II, 86.9; Philon 1929-62). Several issues are touched upon here. One of them concerns the universal genus that is expressed by the indefinite

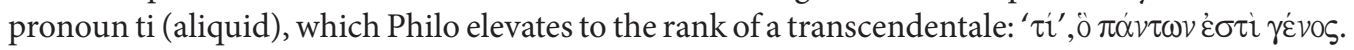
God, on the other hand, occupies to position above the genus that is expressed by the superlative

1 It is highly probable that Philo became acquainted the works of the Platonists that lived in the second half of the 1st century B.C., such as Derkyllides and Eudoros of Alexandria.

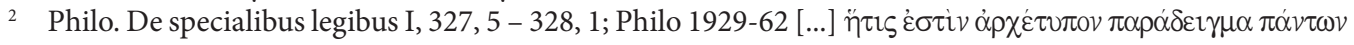

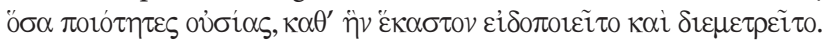

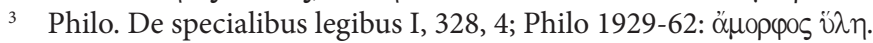

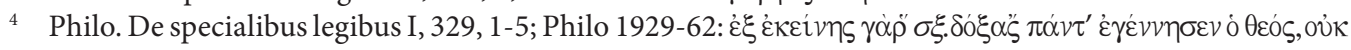

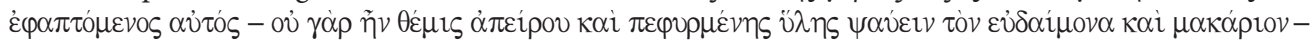

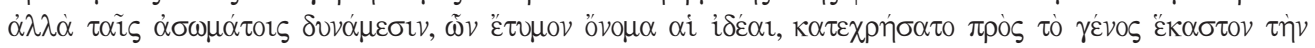

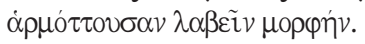

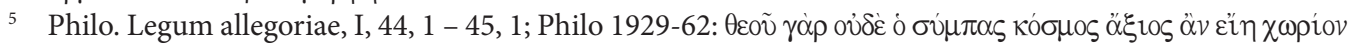

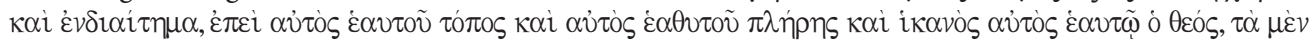

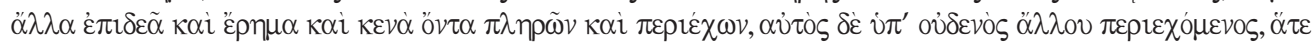

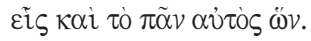


$\gamma \varepsilon \mathcal{L} \kappa \omega \dot{\tau} \tau \tau \tau$ v, which in translations is all too superficially rendered as the "most general"; the second

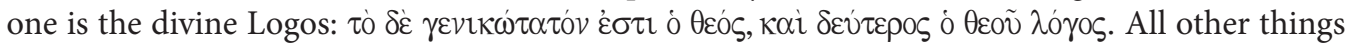
exist owing to the Logos, which means that they in fact occupy a position close to nothingness:

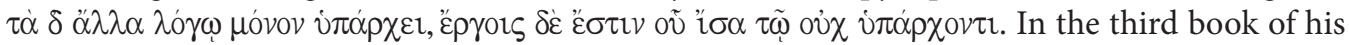
treaty, Philo does not hesitate to use the term $\gamma \varepsilon v i \kappa \omega \tau \alpha \tau o v$ with reference to the transcendental ti

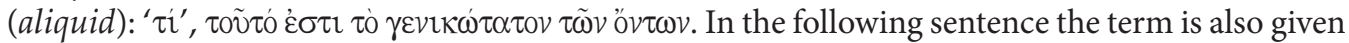

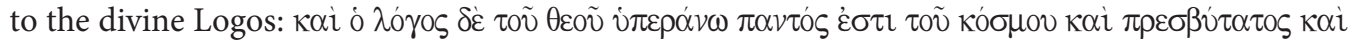

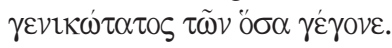

It is worth noting that the idea of a double above-genus, a logical and an ontological one, is clearly present in Porphyry's Isagoge. The term $\gamma \varepsilon \nu \imath \kappa \omega \tau \alpha \tau o v$, is used here quite often and becomes a technical term. The word, as a superlative of the adjective $\gamma \varepsilon v \imath$ kos, meaning not only "generic", but also "ancestral", "original", signifies in one aspect the highest category that is named ovंoi $\alpha$ (nominalized form of the pronoun $\tau \imath$ ) and in the other it is the very first Being that is most generic. Generally speaking, it is a border concept that express the impossibility, i.e. that, on the one

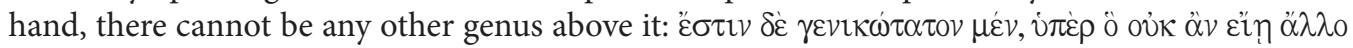
$\dot{\varepsilon} \pi \alpha \nu \alpha \beta \varepsilon \beta \eta \kappa \varsigma_{\varsigma} \gamma \dot{\varepsilon} v 0 \varsigma^{\circ}$ (Porphyry. Commentary 1.4.16; Porphyry 1968), and, on the other hand, it points to the ultimate instance that is individual in nature, and that in human genealogy functions as an ancestor, whereas in the universal aspect it refers to the Deity as the ultimate principle $\varphi \dot{\varepsilon} \rho \varepsilon$

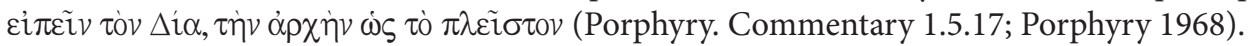

Philo strongly rejects the idea of an anthropomorphic God. He writes in the On the immutability of God:"now the companions of the soul [...] do not compare the living God ( $\tau$ o o

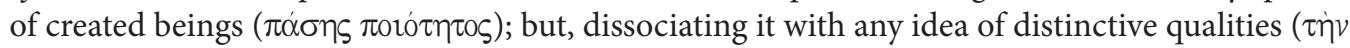

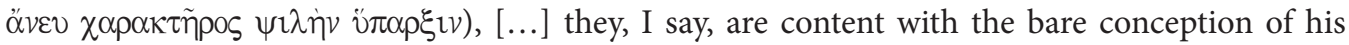

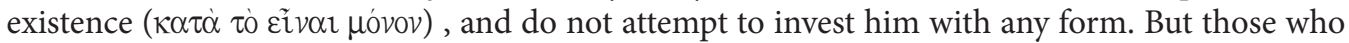
enter into agreements and alliances with the body, being unable to throw off the robes of the flesh , and to behold that nature, which alone of all natures has no need of anything, but is sufficient for itself, and simple, and unalloyed, and incapable of being compared with anything else ( $\kappa \alpha \theta^{\prime}$

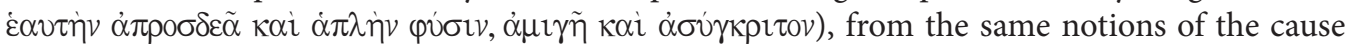

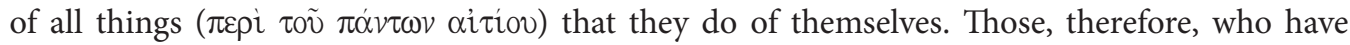
received a fortunate disposition, and an education in all respects blameless, finding the path of life which proceeds in this direction plain and straight, take truth with them as the companion of their journey; by which they are initiated in the true mysteries relating to the living God, and therefore they never attribute any of the properties of created beings to him. [...] But he is

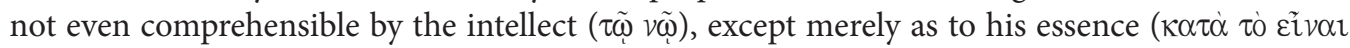

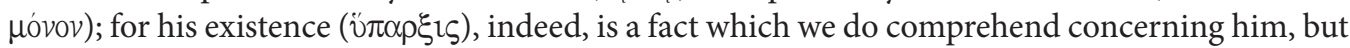
beyond the fact of his existence, we can understand nothing" (Philo. On the immutability of God 55-62; Philo 1929-62).

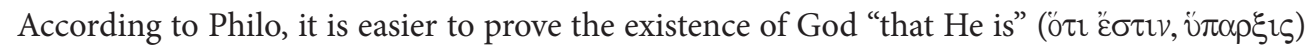
than to grasp His nature, "what He is" ("

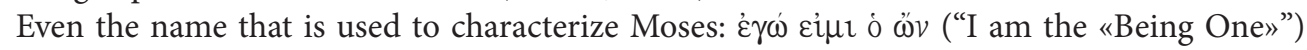
expresses rather the impossibility of any specification. Man should not strive to know His essence, but merely to reasonably confirm in the absoluteness of His existence. The only thing about

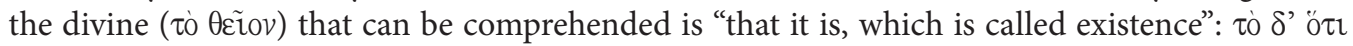

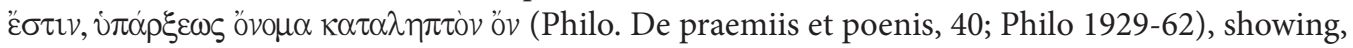
thereby, not - "what it is", but merely "that it is". For His Essence is better than the Good, older than 
the Monad, purer than the One, and cannot be grasped by anything but Himself, because no one else is worth Him (Philo. De praemiis et poenis, 39n; Philo 1929-62)

\section{2. «Originator» or «Creator»?}

The world that we know results from a divine act. What He created had not existed before: "for as he produced that most perfect work, the world, bringing it out of non-existence into existence":

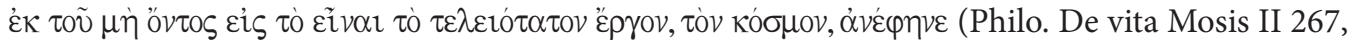
2-3; Philo 1929-62).

"[...] who created the whole universe out of things that had no previous existence": [...] tòv $\tau \dot{\alpha}$ ö $\lambda \alpha$

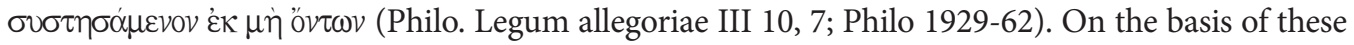
utterances one cannot, however, ascribe to Philo the idea of creatio ex nihilo. The Greek $\mu \eta$ o ov expresses a relative non-Being: "from something that previously was not what He created".

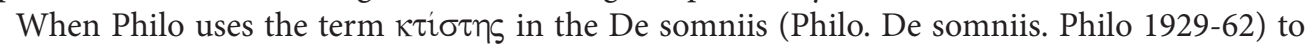
attribute to God the role superior to that of the Demiurge, this does not entail a creation out of nothing. The Demiurge is likened to the Sun that does not create, but merely reveals with its light things that already exist, but cannot be seen in the darkness. Contrasting this with the function of a "creator" ( $\tau \tau i \sigma \tau \eta \zeta)$ shows that God is much more than that: "And besides all this, as the sun, when he arises, discovers hidden things, so also does God, who created all things, not only bring them all to light, but he has even created what before had no existence, not being their only maker, but also their founder" (Philo. De somniis, I, 76, 3 - 77, 1. Philo 1929-62) ${ }^{7}$.

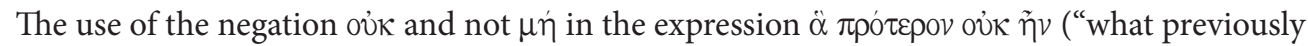
was not") could be interpreted in the direction of a creatio ex nihilo, but the preponderance of Philo's utterances suggests the eternity of the matter.

Thus, one must agree with the opinion that although "it is sometimes maintained that already Philo spoke about the creation out of nothing, the impression has rather been created by the Christian Alexandrian school which used a philosophical apparatus that was very similar to or even identical with Philo’s terminology" (Domański 1989-1990, 34n). J. Domański reminds us, then, that the idea of a creatio ex nihilo finds its origin in in the Vulgate translation of the Old Testament: ex nihilo fecit illa Deus from the Greek fragment of 2 Maccabees of $(7,28)$ : ov่K $\varepsilon^{\xi} \xi$ ” $v \tau \omega v$

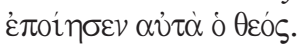

We should note, however, that on a closer look both formulas (the Greek and the Latin one), which are commonly and uncritically accepted as identical, in fact, do not overlap semantically. The Latin version is more radical, as it speaks of a creation of the world out of nothing (resp. nothingness). The Greek version, on the other hand, is surely closer to the original, but it has

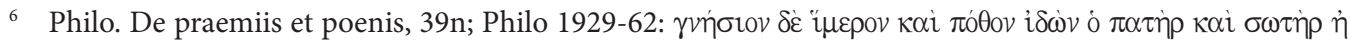

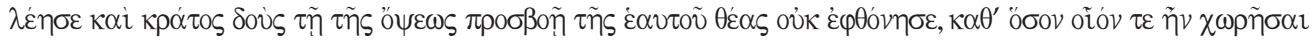

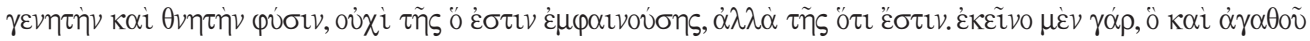

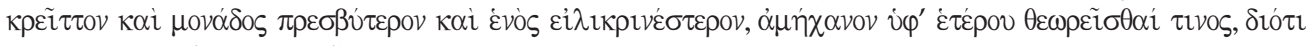

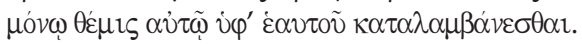

See De vita contemplative where Philo says that those who have „they have been instructed by nature and the sacred laws to serve the living God, who is superior to the good, and more simple than the one, and

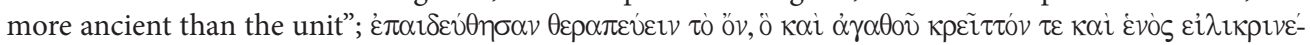

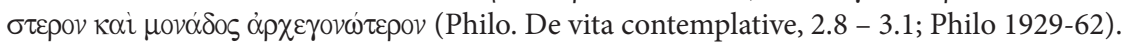

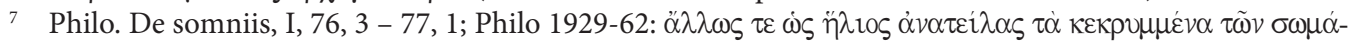

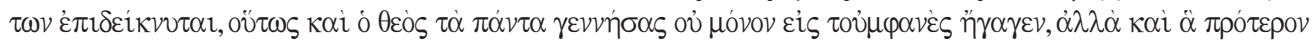

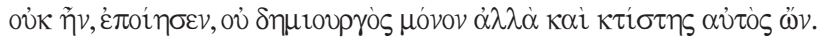


a somewhat different sense: "not out of Beings", i.e. out of ready (actualized things) or elements (for this would entail some sort of reformulation of the already existing world), but out of devoid of qualities and amorphous (not actualized) matter, that is not any Being (for Being is something that is a formed one, $s c$. something definite), albeit it is not nothingness, either.

It is clear, then, such a reading is determined by placing at the beginning the negation "no" that is immediately separated by the preposition "with", which does not allow to connect it directly to the "Being" that would automatically yield its absolute opposition "Non-Being". Thus, in the Greek version we have the following sequence: "not out of Beings did God make those things", where the negation is evidently related to the predicate, and not to the Beings! In the Latin version, it is the other way round: it is suggested here (and this is a misuse) that God created the world out of nothing (absolute Non-Being), i.e. nothingness. This is also the general understanding of the creatio ex nihilo formula. This change can be explained by the fact the later Christian philosophy tried to make God entirely independent of the matter, rendering, thereby, the latter quite superfluous. The nothingness, on the other hand, is not some metaphysical fore-substrate that would exist as something even more abstract than the unformed matter. The crucial novum is here that the emphasis has been put on the absolute freedom or indeterminacy of God in the act of creation. This "made out of nothing" means: God created the world not out of matter, not out of nothingness as some preexisting substrate, but caused it to emerge by the strength of the divine fiat!, thus, by the infinite strength of his absolute free will that absolutely does not require anything else for this purpose.

\section{The Unnamed, and yet Named "the Being One": the premises of Onto- theology}

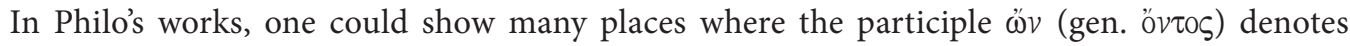
simply God in a closer or further context, and the philosopher uses for that purpose the plain form $\theta \varepsilon$ cos. God himself uses the term, as is testified by the Greek translation of the Septuagint:

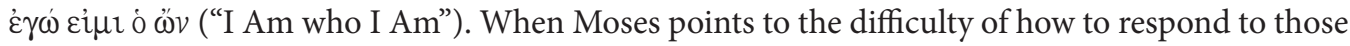

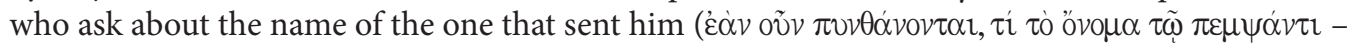
Philo. De vita Mosis I 74, 3; Philo 1929-62), God replies: "At first say unto them, I am that I am, that when they have learnt that there is a difference between him that is and him that is not, they may be further taught that there is no name whatever that can properly be assigned to me, who I am the only being to whom existence belongs" (Philo. De vita Mosis I, 75, 1; Philo 1929-62) Philo explains: "Since God alone exists in essence, on account of which fact, he speaks of necessity about himself, saying, I am that I Am, as if those who were with him did not exist according to essence, but only appeared to exist in opinion" (Philo. Quod deterius potiori insidiari soleat, 160, 7-9; Philo 1929-62)9.

When asking the question "is there a name for that Being, Moses was perfectly aware that "even the name Lord is not at all worthy of Him" (Philo. De somniis, I, 230, 3-4; Philo 1929-62) ${ }^{10}$. No

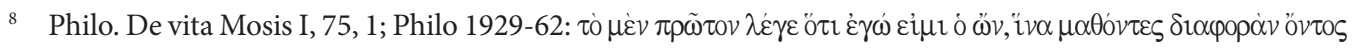

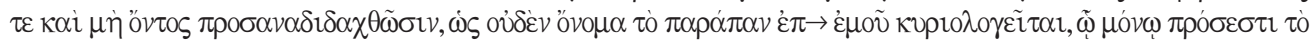
Eival.

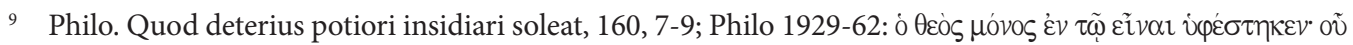

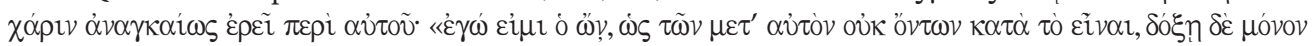

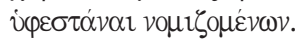

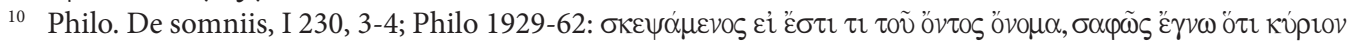

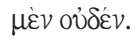


specificity applies to Him. Philo elucidates: "for the living God is not of a nature to be described, but only to be" (Philo. De somniis, I, 230, 5 - 231,1; Philo 1929-62) ${ }^{11}$. God says: «I am that I Am, that the questioner might know the existence of those things which it was not possible for man to conceive not being connected with God" (Philo. De somniis, I, 231, 1-3; Philo 1929-62)12.

Here are other places in Philo where the naming appears. He speaks of the autonomy of "He who

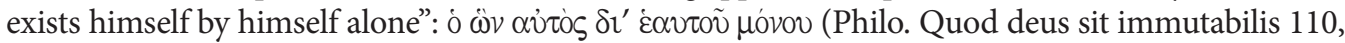

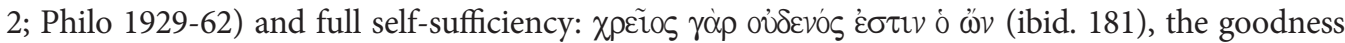

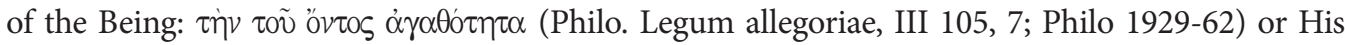

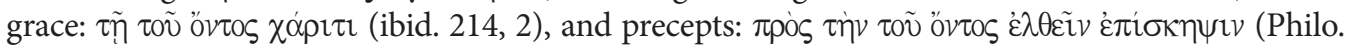
De migratione Abrahami 195, 10 - 196, 1; Philo 1929-62), and trustfulness, in connection with

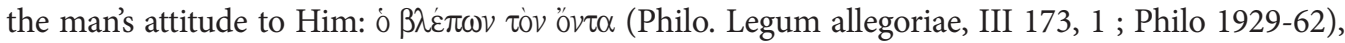

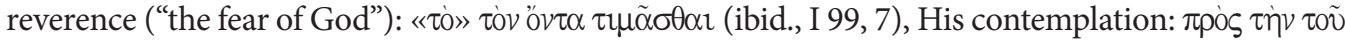

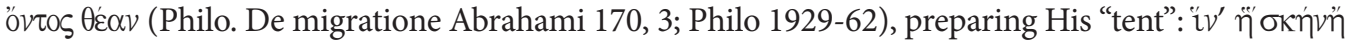

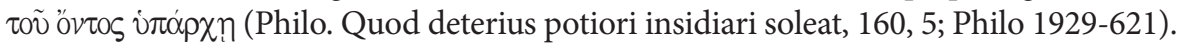

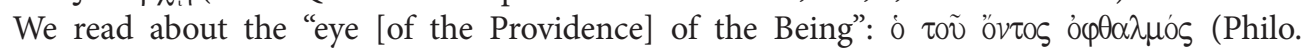

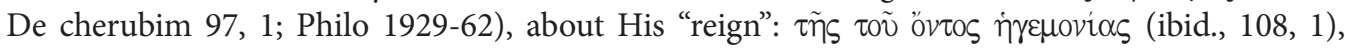

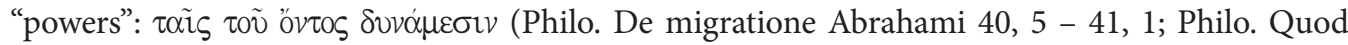
Deus sit immutabilis 109, 2; Philo. Quod deterius potiori insidiari soleat, 159, 3; Philo 1929-62).

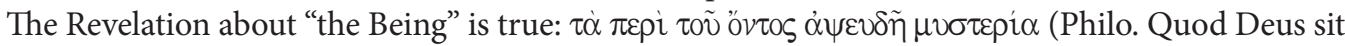
immutabilis 61, 5-6; Philo 1929-62), what we know about the Being is wonderful in comparison to

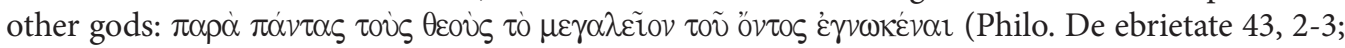
Philo 1929-62), for the knowledge of the living God having beamed upon it, out-dazzles everything

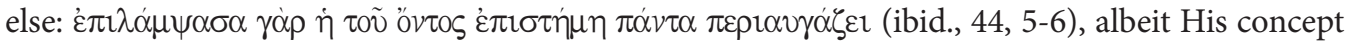

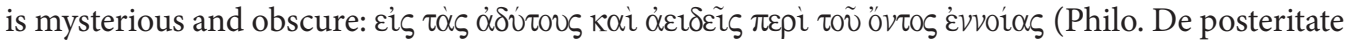
Caini 14; Philo 1929-62), and ascribing to Him such states as anger, fear, sorrow and pleasure must

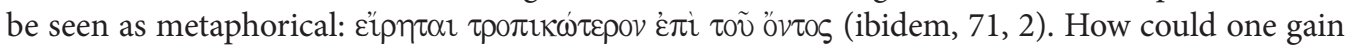

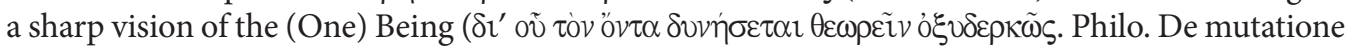
nominum 82, 2-3; Philo 1929-62), and is there someone who could comprehend the final stage

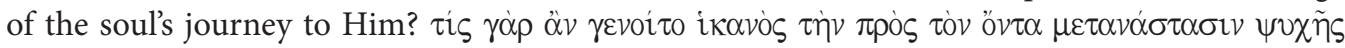
$\tau \varepsilon \lambda \varepsilon i \alpha \varsigma$ (Philo. De sacrificiis Abelis et Caini 10, 2-3; Philo 1929-62).

The above examples use the participium masculini $\omega v$, showing, thereby, the personal character of God. In other places, Philo employs the abstract neutrum form tò oै $v$ which expresses the general sphere of the Divine transcendence. Such an understanding is expounded further in the treaty

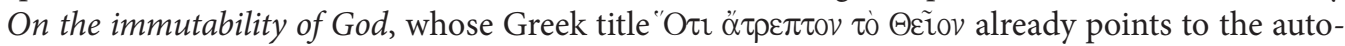
referentiality of the Divine. Instead of the personal description "God", Philo prefers to call it "Being" (as participium), speaking, for example, about Abraham's experiencing the unshakable

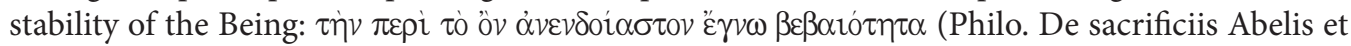
Caini 4, 10; Philo 1929-62).

This understanding of immutability by Philo is clearly reminiscent of Parmenides' Being in Plato's Sophist: "But for heaven's sake, shall we let ourselves easily be persuaded that motion

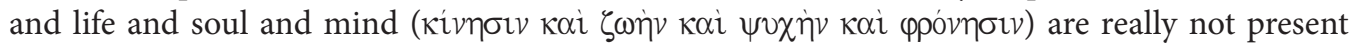
to absolute being $(\tau \tilde{\omega} \pi \alpha \nu \tau \varepsilon \lambda \tilde{\omega} \varsigma$ o

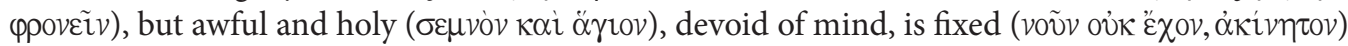

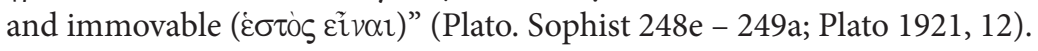

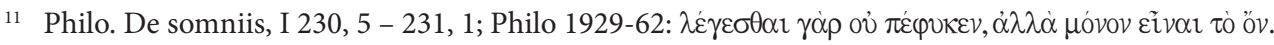

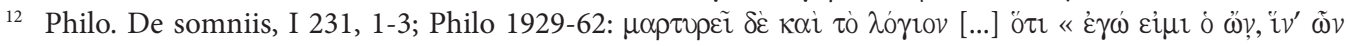

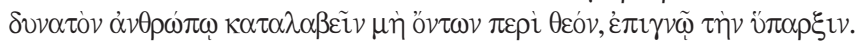


This passage from the Sophist seems to be echoed in the Neoplatonic identification of the eidetic (i.e. Being-Idea) sphere with the Nous ( $\varepsilon v$ o ov) which Philo also anticipates, although he situates God at the eidetic level, lowering, thereby, his position in relation to the trans-transcendent

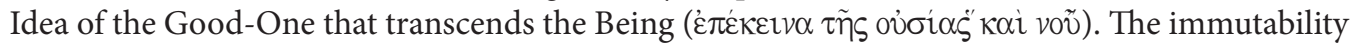

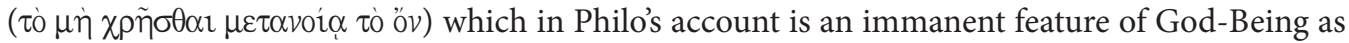
a thinking-nature. In contrast to man, the Creator of all-things, possesses constantly the unshakable and a priori powers: reflection (consideration) and decision, controlling, thus, his works: "̌vvotav

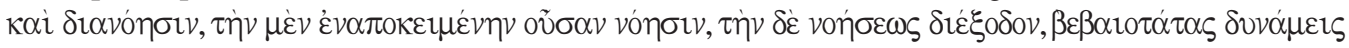

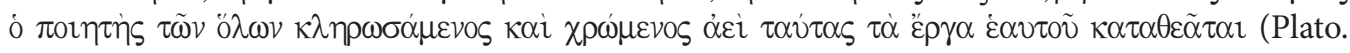
Sophist 34.1-5; Plato 1921, 12).

\section{God as Esse absolutum}

Of special importance for us is the case of the De mutatione nominum (Philo. De mutatione nominum 27,1-5; Philo 1929-62) where a direct reference to the Aristotelian formula of the Absolute is to be found: $\tau$ o o $\nu \tilde{n}$ ”ov. The author employs the formula to emphasize the self-referentiality of this

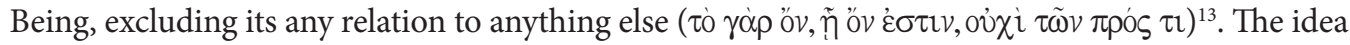
occurs in the context, when Philo argues that in the famous phrase from the Old Testament "I am thy God" the final pronomen possessivum бó ("thy") can only be understood metaphorically, since God as an autorelative has no relations to anything, but rather is a Being in itself: "does not consist in relation to anything; for he himself is full of himself, and he is sufficient for himself" (Philo. De mutatione nominum 27, 4-5; Philo 1929-62) ${ }^{14}$ and further: "for he himself is full of himself, and he is sufficient for himself, and he existed before the creation of the world, and equally after the creation of the universe" (Philo. De mutatione nominum 27, 4-5; Philo 1929-62) ${ }^{15}$.

Philo's argument gains full conclusiveness only when the enthymematic premise reducing the concept of Being to God is revealed. In the next fragment, he introduces yet another synonym, this time of Platonic origin: $\tau$ o o ov $\tau \omega \varsigma$ ऽ o $v$ ("that what is really Being") and enriched by

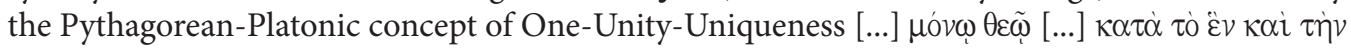
$\mu o v \alpha ́ \delta \alpha, \tau o$ ö $v \tau \omega \varsigma$ öv (Philo. Quod Deus sit immutabilis 11.4-12.1; Philo 1929-62). The syntactically

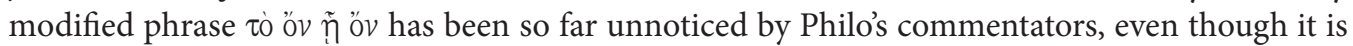
his hapax legomenon. The Alexandrian gives a different, more radical meaning to the expression that it had in the Books G and E of Aristotle's Metaphysics. It is closer to the inauthentic Book K.

In this Book, the formula refers to an unspecific, although clearly monotheistic Deity. It is conceivable that Philo was inspired by the Book K, although he introduced the personal God. The Metaphysics might have been known in the Alexandrian circles as Aristotle's work, but its Book K has been show by modern research (Natorp, Aubenque, Berti) to definitely be inauthentic ${ }^{16}$. Thus, the theologizing understanding of the $\tau$ ò ôv $\tilde{n}$ oैv formula cannot be attributed to Aristotle.

13 The original understanding of Aristotle’s formula is discussed extensively by J. Bigaj, Zrozumieć metafizykę (Bigaj 2005).

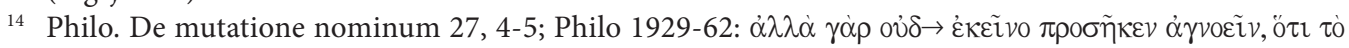

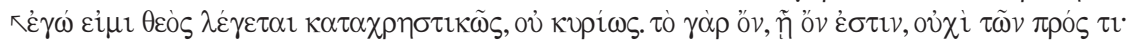

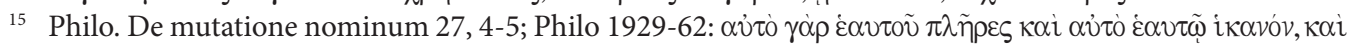

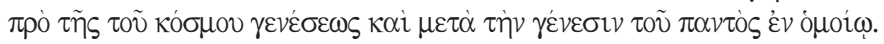

16 The inauthenticity of the Book K has been convincingly demonstrated by P. Natorp in his paper from 1888 (Natorp 1888, 178-193). Some one hundred years later, P. Aubenque summarizes the results of the research on this Book, stating definitively: " $\mathrm{K}$ is later than BGE and its purpose is summary. [...] Aristotle is not the author of the summary" (Aubenque 1983, 343). 
The authentic understanding is to be found in the Books G and E, if - as has been suggested by Natorp - the interpolated sentences are removed from the latter and in the others the correct philological understanding is maintained.

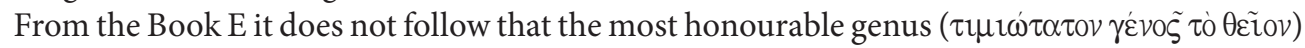
should "dethrone" to ôv $\tilde{n}$ " ov as the only legitimate subject of the first philosophy ${ }^{17}$. The major problem of the Book $\mathrm{E}$ is the problem of the primacy of philosophy understood as the very first from the abilities (explaining the beings/things/facts distributively), and not some distinctive object that would determine its primacy. Its primacy is not due to its being some "supraphilosophy", but rather due to the universality of its method, i.e., due to the fact that it can (albeit does not have to) deal with the most dignified Being. To this formula $\tau \dot{0}$ ôv $\tilde{n}$ ö $v$ (exchangeable with $\tau \dot{\alpha}$ oै $v \tau \alpha \tilde{\eta}$ o $v \tau \alpha$ ) belongs the ti/ e)sti question, namely, that a given being (natural form/ matter compound substance) has inalienable properties, of which a simple supranatural divine entity is simply devoid ${ }^{18}$.

The concept and object of philosophy understood as a universal ability to explain all things without being limited to one subject discipline is constituted in the opening sentences of the Metaphysics' Book $\mathrm{G}$ with the use of the expression to ô $v$ ก oै $v$ : “There is a science which studies

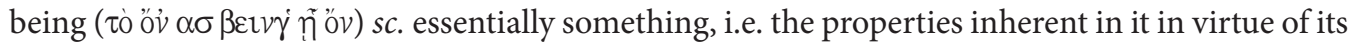
own nature. This science is not the same as any of the so-called particular sciences" (Aristotle. Metaphysics G 1, 1003a 21-23; LCL 271) ${ }^{19}$.

The formula ôv ก๊๊ oै $v$ from the Book G receives the theological sense of naming "The Being that fully is" of transcendent character in a paraphrase of the Books GE which belongs to the Book K, an apocryphal work that originated in II/I century B.C, when the Metaphysics was complied ${ }^{20}$. It is there that the author flatters himself for having found a philosophically proper description for the transcendent Essence: $\tau$ ò ôv $\tilde{\eta}$ öv ("The Being as «Being»"). In this formula, he found an elaboration of the simple $\tau$ ò $\circ v \beta \psi$ ก๊ o $v$, which in the book G expressed only the manner

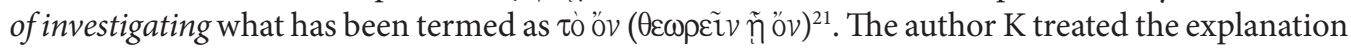

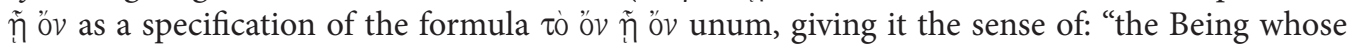
essence can be reduced to the «Being»" This is reminiscent of the Biblical "I Am that I Am", which suggests an influence of the Old Testament's monotheism.

In this way, the theological interpretation of the "Being" ( $\tau$ ò öv) "as Being" (ๆ๊ ôv), would be prepared approximately one hundred years before Philo by the editor of the Metaphysics, which

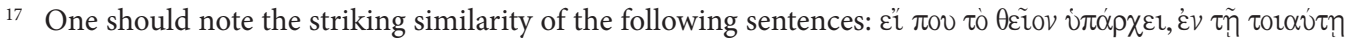

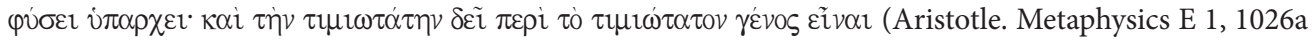

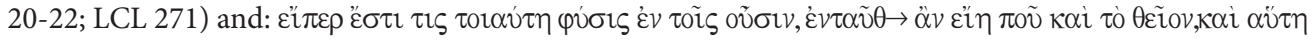

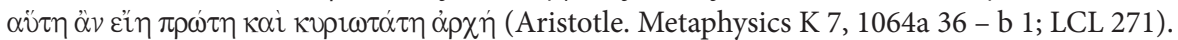

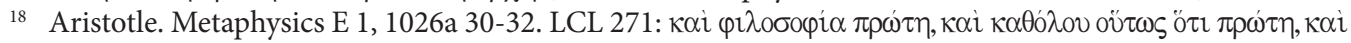

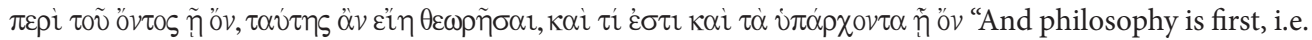
universal. Thus, if it is first then it is to study being as being, i.e. what it is and what is ascribable to it as being something" (my own corrected translation).

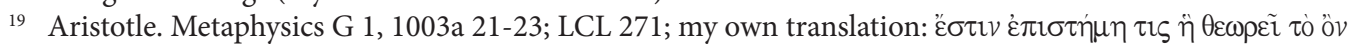

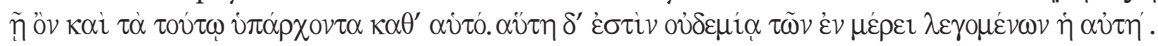

20 P. Natorp ascribes the authorship of the book K to "an older Peripatetic" (durch einen älteren PeripatetikerNatorp 1888, 193). A detailed research makes it nevertheless necessary to postpone the date of the origin of this paraphrase of the books BGE to II/I century B.C. For an extensive discussion of this issue see Bigaj 2013, 42-66).

${ }^{21}$ One should note that a similar mistake has been notoriously made in rendering the related expression:

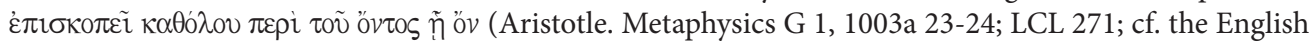
translation by $\mathrm{H}$. Tredennick: "contemplates Being generally qua Being). 
enabled the Alexandrian to view "the Being God" as auto-referential and relationless Being. The editor of the Metaphysics and, at the same time, the author of the K paraphrase, finds in this $\tau$ o o $v$ ก๊ oै $v$ the distinctive "Beingness" that is different from everything that is characterized as $\tau \dot{\alpha}$ " $\nu \tau \tau \alpha$, introducing, thereby, a certain dualism into the specification "ov. By distinguishing the "inbred"

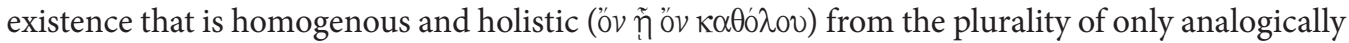
called partial "existences" (" $\left.\nu \tau \alpha \kappa \alpha \tau \alpha \mu \dot{\varepsilon} \rho{ }^{\prime}\right)$ ), in a contrast to the later metaphysics that pushes for the view of homogenous "Beingness" in the sense of existence, the ontic boundary between various types of beings, including God (summum ens) and creations, is blurred, and remains only a matter of degree,

It is symptomatic that the author of the Book K, fascinated by the formula ô $v$ ñ oै $v$ that reduces "Being" to itself, omits in his paraphrase entirely the reduction, introduced in the Book G and later

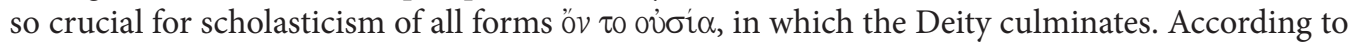
Franz Brentano (Brentano 1862) in ovoi $\alpha$ all Beingness is gathered ${ }^{22}$, whereas C. Braig sees the full Beingness in God. In this view, as has been observed by Heidegger, God becomes the quintessence of Being as the most supreme ou)si/a (suprema concrezione dell' ovं $i^{\alpha} \alpha$ ), and "ontology transforms into theology" (lontologia si converte in teologia) (Berti 2005, 396). In Brentano's position, one can find a transition from analogia to univocitas entis. Homogeneity, to the point of univocity, can also be discerned in Heidegger's concept of Being (Sein), which he correctly refuses to find in Aristotle's metaphysics. For the K author, on the other hand, the two distinctive spheres remain heterogeneous in their "existence", the former is transcendent $(\chi \omega \rho \imath \sigma \tau \eta /)$ and included ( $\pi \varepsilon p 1 \varepsilon \chi \varepsilon \tau \alpha \imath)$ by the other, showing with it certain union (Kouvóv), under the relation of subordination, i.e. as one may conjecture - inferiority to the Creator. Here Heidegger erroneously ascribes to this "union" (Kouvóv) of Being from the Book K a mediation by ovंбi $\alpha^{23}$, since the term does not occur in the paraphrase of the Book G not even once (!), as it is consciously and consistently disregarded by the author. That is why God is not presented there - as Heidegger would have it - as summum ens, i.e. "«Being», in whose «existence» manifests itself in the highest sense" (ed infine Dio viene presentato come il summum ens, cioè come l'ente nel quale l'essere si manifesta nel senso più alto) (Berti 2005, 398), but merely as "Being itself" ( $\tilde{\eta}$ öv) in an exclusive, full and unique sense. The

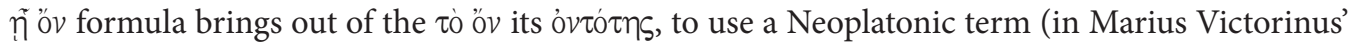
Latin translation: exsistentialitas vel essentitas) that accentuates the fullness of the transcendent One-Being. In the sphere of the "Being itself", one is struck by the similarity to the Parmenidean

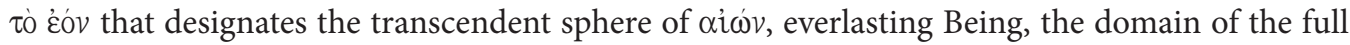
and timeless Truth. Philo's use of the term to oै $v$ with reference to God has been continued by other thinkers, independent of the Alexandrian theologian, first Plutarch, then Numenius, who

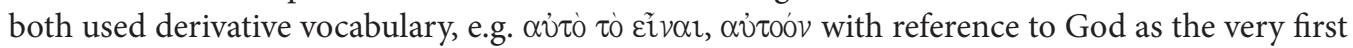
Cause, which was quite different from the Neoplatonic thinkers, for whom it was an infinitively active (inexhaustible) Pre-Being One ${ }^{24}$ that was logically prior to the Being (Noṽ $)$ and, thereby,

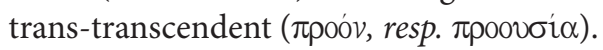

22 E. Berti revels a charge against Brentano because of that: „Ma l'interpretatione di Brentano, secondo cui i molteplici significati dell'essere distinti da Aristotele si riducono tutti all' ov̉oi $\alpha$, è insoddisfacente per varie ragioni” (Berti 2005, 400).

23 „La «riduzione» $(\dot{\alpha} v \alpha \gamma \omega \gamma \eta /)$ in questione, per la quale Heidegger si rifà sopratutto al libro K della Metafisica (dove effettivamente l' ov̉oí è concepita come un kotvóv), viene presentata come fondata sulla scolastica analogia attributionis, intesa come «partecipazione» dei vari significati al primo" (Berti 2005, 397-398).

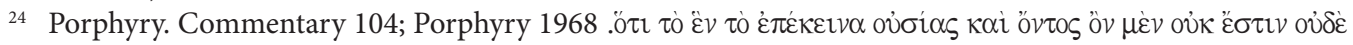

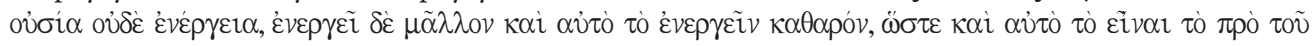
övtos. 


\section{REFERENCES}

Aristotle. Metaphysics LCL 271. Treddennick, Hugh (ed.). Aristotle. Metaphysics. Books I-IX, Loeb Classical Library 271. ed. Cambridge Mass 1989.

Aubenque, Paul. 1983. Sur l'inauthenticité du livre K de la Métaphysique, Zweifelhaftes in Corpus Aristotelicum. Studien zu einigen Dubia. Berlin-New York.

Berti, Enrico. 2005. La 'Metafisica' di Aristotele: «onto-teologia» o «filosofia prima»? In Berti, Enrico. Nuovi studi aristotelici. II. Fisica, antropologia e metafisica, Editrice Morcelliana, Brescia.

Bigaj, Jan. 2005. Zrozumieć metafizykę, vol. I, part. 2. Ustrzyki Dolne.

Bigaj, Jan. 2013. Dlaczego «Pseudo-Arystoteles»? Ustrzyki Dolne.

Brentano, Franc. 1862. Von der mannigfachen Bedeutung des Seienden nach Aristoteles, Freiburg. Domański, Juliusz. 1989 - 1990. "Stworzenie z niczego", kilka uwag o genezie i rozwoju pojęcia. In Roczniki Filozoficzne 37-38, 31-41.

Heidegger, Martin. 1969. The Onto-theo-logical Constitution of Metaphysics, In Identity and Difference. Translated and with an introduction by J. Stambaugh. New York, 42-76.

Heidegger, Martin. Introduction to "What is metaphysics?", translated by M. Groth. https://wagner. edu/psychology/files/2013/01/Heidegger-What-Is-Metaphysics-Translation-GROTH.pdf

Natorp, Paul. 1888a. Thema und Disposition der aristotelischen Metaphysik. In Philosophische Monatshefte 24, 37-65; 540-571.

Natorp, Paul. 1888b. Ueber Aristoteles, Metaphysik K 1-8, 1065a 26. In Archiv für Geschichte der Philosophie 1, 178-193.

Philo. De cherubim

Philo. De ebrietate

Philo. De migratione Abrahami

Philo. De mutatione nominum

Philo. De posteritate Caini

Philo. De praemiis et poenis

Philo. De sacrificiis Abelis et Caini

Philo. De somniis

Philo. De specialibus legibus

Philo. De vita contemplative

Philo. De vita Mosis

Philo. Legum allegoriae

Philo. Quod deterius potiori insidiari soleat

Philo. Quod deus sit immutabilis

Philo 1929-62. Philo. Translated by F. H. Colson, G. H. Whitaker and R. Markus. Loeb Classical Library, 10 vols. and 2 supplementary vols. Cambridge.

Plato, Sophist 1921. Plato in Twelve Volumes. Vol. 12. Translation by Harold N. Fowler. Cambridge, MA - London.

Porphyry. Commentary; Porphyry 1968. Porphyry's Commentary on Plato's Parmenides. In Hadot, Pierre. Porphyre et Victorinus. vol. II. Paris.

SUMMARY: PHILO OF ALEXANDRIA AND THE ORIGINS OF ONTO-THEOLOGY. Seeking the sources of the radical formulation of the issue of metaphysics as onto-theology by M. Heidegger (1957), we find the definitive analyses of Aristotle's Metaphysics by P. Natorp (1888) and P. Aubenque (1983), and in more distant past, Philo's of Alexandria (around $20 \mathrm{BC}-40 \mathrm{AD}$ ) theological interpretation of Being, probably inspired by the Book 
Kappa of this work. P. Natorp was the first to demonstrate the contradiction in Aristotle's "first philosophy" in terms of its dual components, as this philosophy was understood, i.e. at the same time as the science of all being and of the Supreme Being. This contradiction was a result of the failure to recognize that Aristotle did not write certain parts of the Metaphysics (Book $\mathrm{K}$ in particular), on the one hand, and the erroneous interpretation of its genuine content on the other. Ignoring this important reservation, Heidegger attributed to Aristotle's metaphysics the domination of the theological component over the theological, although this reservation is not totally incorrect with respect to the medieval metaphysics, which identified God with Being itself. This identification is rooted in the imposition of the maximalist concept of Being (originating in Parmenides and Plato) onto a personal God. The first trace of the merging of the two ideas can already be found in the compiler of the Book $\mathrm{K}$ in his theological understanding of Aristotle's formula to on hē on (being as being), but explicitly the reference of this formula to God (hitherto unnoted by commentators) can be found in Philo, who can be treated as the actual originator of onto-theology. On the other hand, to Aristotle's genuine "first philosophy" could be ascribed two non-equivalent components: one general-ontological, focused on "being as being", and the other, subordinate to it the theological one, focused on the "most honorable genus".

\author{
Seweryn Blandzi, Professor \\ Polish Academy of Sciences \\ Institute of Philosophy and Sociology \\ Dep. Of Ancient Philosophy And History of Ontology \\ Nowy Swiat 72 \\ 00-330 Warsaw \\ Poland \\ rekta@pro.onet.pl
}

